\title{
Multi-year distribution patterns of nutrients within the Neuse River Estuary, North Carolina
}

\author{
Robert R. Christian ${ }^{1}$, Joseph N. Boyer ${ }^{1,2, *}$, Donald W. Stanley ${ }^{1,2}$ \\ ${ }^{1}$ Biology Department and ${ }^{2}$ Institute for Coastal and Marine Resources, East Carolina University, Greenville, North Carolina \\ 27858-4353, USA
}

\begin{abstract}
Spatial and temporal patterns of nutrient distributions in the Neuse River Estuary, North Carolina, were assessed from a 4 yr study involving 82 longitudinal transects of the estuary. This major, river-dominated estuary receives water from a $16000 \mathrm{~km}^{2}$ drainage basin and is connected to the Atlantic Ocean by Pamlico Sound. Concentrations of nitrogen and phosphorus species and chlorophyll a were measured in association with environmental factors. Intrastation distributions of variables were generally non-normal, and interstation distribution patterns varied considerably between species measured. Concentrations of dissolved species decreased down-estuary, although internal sources of both ammonium and filterable reactive phosphorus were apparent. Particulate species demonstrated maxima in the upper estuary associated with autochthonous production. The relative isolation of the Neuse River Estuary from ocean inputs and long flushing times of freshwater provide an environment which promotes nonconservative mixing of nutrient species. The average flushing time for the estuary was $51 \mathrm{~d}$ providing an extended period within the estuary for substantial recycling. Thus distribution patterns reflect the dominance of biological and chemical activity except when large freshets cause rapid movement of water to the lower estuary and out into Pamlico Sound.
\end{abstract}

\section{INTRODUCTION}

A variety of factors interact to determine the distribution of nutrients in an estuary. First, the concentrations at the estuary's head and mouth set initial conditions. Concentrations throughout the estuary then depend on the rates of physical, chemical, and biological processes. Flushing and mixing tend to act similarly on various dissolved nutrients or on particulate forms. Chemical and biological processes act on different nutrient species at different rates varying as the community responds to environmental factors. Resultant concentration patterns depend on the order of time scales of the various processes (Imberger et al. 1983, Peterson et al. 1985).

Numerous researchers have used property versus salinity plots to examine the relative importance of physical mixing to nutrient concentration patterns and

- Present address: Rt. 4, North Wiltshire, Prince Edward Island, Canada COA 1 YO to locate sources and sinks within estuaries (Boyle et al. 1974, Officer 1979, Peterson et al. 1985). Seasonal patterns have been noted for several estuaries, including the Delaware, Chesapeake, and Hudson Bays in North America and the Loire River estuary in France (Sharp et al. 1986, Fisher et al. 1988, Meybeck et al. 1988, Horrigan et al. 1990). Extended interannual patterns have been described less frequently, but have been reported for northern San Francisco Bay, USA (Peterson et al. 1985). In this estuary, concentrations of ammonia, nitrate plus nitrite, and phosphate followed seasonal patterns associated with biological activity which were modified by rainfall and flow as these factors changed interannually. The aforementioned estuaries have both significant riverine inputs of water that control the horizontal salinity structure and significant riverine inputs of nutrients which represent the major sources of these substances. Several generalities can be stated from the results of these and similar studies. First, low flow and warm/high-light seasons, by promoting extended residence times and enhanced 
biological activity, are associated with greater deviations from conservative mixing than high flows and cool/low-light seasons. Second, the locations of estuarine sinks for nutrients are often associated with chlorophyll maxima which move horizontally in response to flow. Third, when present in high concentrations in the incoming fresh water, nitrate is often rapidly depleted in the estuary. And, fourth, estuarine sources of ammonia and phosphate can be observed under a variety of conditions. Some of these characteristics are explained in the conceptual model of interactions between phytoplankton, nutrients and turbidity described by Fisher et al. (1988). Also, the expected patterns of distribution are related to relative time scales of biological and chemical processing, physical mixing and transport, and transfers between water and air, sediment and/or land. Conservative mixing patterns are more pronounced when physical processes occur at shorter time scales than biological or chemical processes (Imberger et al. 1983).

We conducted a 4 yr study of the relationships of nitrogen loading to cycling in the Neuse River Estuary, North Carolina. The patterns of most process rates are described elsewhere (Boyer et al. 1988, Boyer et al. unpubl., Stanley et al. unpubl.), but considerable data were collected on the distribution of nutrient concentrations under a variety of environmental conditions. Here we describe the patterns of nutrient standing stocks in the context of flushing time (time required for river flow to replace freshwater in the estuary) and potential biological activity. First, we consider the overall patterns of nutrient concentrations within and among stations for the $4 \mathrm{yr}$ of study. From withinstation results, we describe aspects of the frequency distributions of the data which have implications for interpreting expected variability. From results among stations we summarize the spatial distributions of nutrients. Second, we evaluate temporal patterns of change and correlative associations using seasonally averaged, volume-weighted means of nutrient concentrations and environmental factors. Lastly, property versus salinity plots of nutrients are used to evaluate mixing characteristics in the context of estuarine location. These are shown for conditions of long and short flushing times interacting with high and low temperatures to evaluate the relative impacts of flushing and biological activity potential.

\section{The Neuse River Estuary}

The Neuse River Estuary (Fig. 1) is a major subestuary emptying into the southwestem corner of Pamlico Sound, North Carolina. The river and estuary drain $16000 \mathrm{~km}^{2}$. Most of the watershed is comprised of

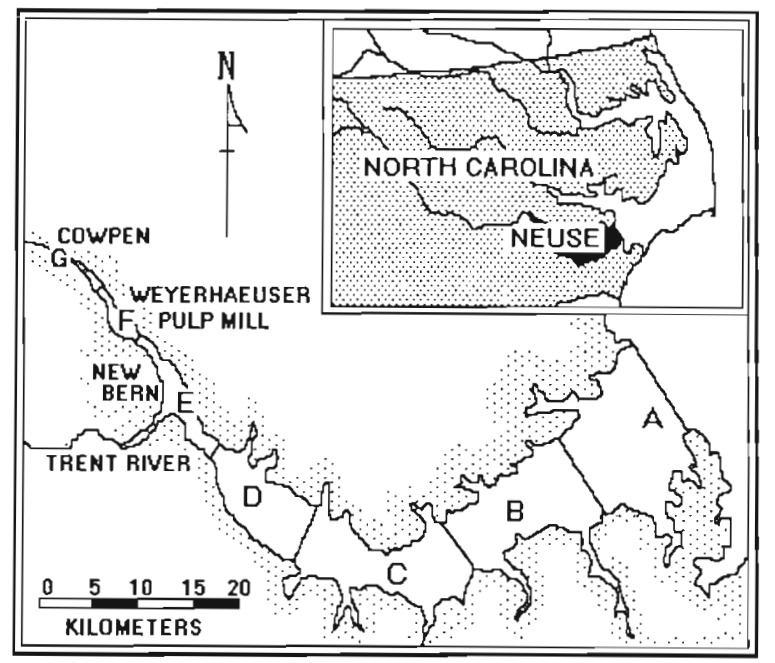

Fig. 1. Neuse River Estuary, location of sampling stations and division lines for segment delineation

forest ( $64 \%$ ), followed by agricultural cropland (26\%), with urban use being only $3 \%$ (Stanley 1988). Over one million people live within the watershed. Stanley (1988) calculated a nutrient budget for the basin based on land-use categories and coefficients of nutrient release. In 1985, 7800 metric tons of nitrogen and 1700 metric tons of phosphorus were calculated as potential inputs to the Neuse River. Seventy-six percent of the total nitrogen loading and $70 \%$ of the total phosphorus loading came from non-point sources. The remainder was from 16 municipal and industrial point sources. The largest discharge is from a paper pulp mill between Stns G and F (Fig. 1) just above the head of the estuary.

The system is considered eutrophic with periodic blooms of the cyanobacterium Microcystis aeruginosa occurring in the river in summer (Christian et al. 1986, Paerl 1987). There is generally little evidence for nutrient limitation within the lower river (Paerl 1987), but dissolved inorganic nutrients, especially nitrate, decrease within the upper estuary such that limitation may occur at times within the estuary (Hobbie \& Smith 1975, Christian et al. 1984, 1989).

\section{METHODS}

Sample collection and analysis. Samples were collected at 2 to 3 wk intervals from March 1985 through February 1989. The shorter intervals were used during warmer months; occasionally longer intervals resulted from poor weather conditions or boat or equipment failure. Seven sites were sampled (Fig. 1), starting at the estuary's mouth (A) and the lower estuary (B), continuing to the prominent dogleg at Wilkerson Point 
(C), through the upper estuary (D and E), and into the river ( $F$ and $G$ ). Each site was considered to represent a segment of estuary or lower river. Segment interfaces were set at half the distance between neighboring sites.

Dissolved oxygen $\left(\mathrm{mg} \mathrm{l}^{-1}\right)$, temperature $\left({ }^{\circ} \mathrm{C}\right)$, and salinity (ppt) were measured in the field at $0.5 \mathrm{~m}$ depth increments throughout the water column using a YSI Model 57 oxygen meter and a YSI Model 33 meter for temperature and salinity. We routinely collected $3.5 \mathrm{l}$ water samples ca $0.2 \mathrm{~m}$ below the surface and periodically took samples near the bottom during periods of stratification. Samples were transported to the laboratory in the dark at ambient or lower temperature, and were processed within $7 \mathrm{~h}$ after collection. To assess the variability of nutrient concentrations within a station and sample run, on 11 May 1988 we collected 7 samples of 3.51 from Stns A, C, D, and G, and analyzed duplicate samples from the sample containers.

Filtered water (Whatman 934-AH) was stored frozen or refrigerated for later analyses of nitrate plus nitrite $\left(\mathrm{NO}_{x}\right)$, ammonium $\left(\mathrm{NH}_{4}\right)$, filterable reactive phosphorus (FRP), and dissolved Kjeldahl nitrogen (DKN). Analyses followed USEPA (1979) and APHA (1985) procedures with digestions according to Jones \& Bradshaw (1989). During the last 2 yr, urea was also measured (McCarthy 1970). Preliminary studies showed there was little nitrite in samples; therefore we routinely measured nitrate and nitrite as one and assumed the pool to be primarily nitrate. Most often, $\mathrm{NH}_{4}$ analyses were done within $1 \mathrm{~d}$ of sampling with cold storage. Material on filters was frozen for later analyses of chlorophyll a ( $\mathrm{chl}$ a) $\left(\mu \mathrm{g} \mathrm{l}^{-1}\right)$, particulate nitrogen (PN), and particulate phosphorus (PP) following procedures in aforementioned references. $\mathrm{NO}_{x}$, FRP, DKN, PN, and PP were analyzed with an Orion Scientific Instruments Corporation segmented flow analyzer; other analyses were done manually. All nutrient results were recorded as $\mu \mathrm{M}$.

Data analyses. Data from 82 sampling trips were compiled for analysis. We assessed data distributions by calculating the arithmetic mean, standard deviation, coefficient of variation, skewness and kurtosis for each of the stations from the $4 \mathrm{yr}$ of study. Calculations of the various statistical moments were made using SYSTAT (Wilkinson 1988). We assumed the value of the lower limit of detection when concentrations were below this limit. We assessed temporal patterns using traditional seasons as units of averaging data. We indexed the hydrologic regime of the estuary using the model of Ketchum (1951) as adapted by Pilson (1985). The volume of each segment (surface area $\times$ depth) was determined from nautical charts. For surface area we weighed paper cut-outs of each segment and compared these weights to cut-outs of a standard area. For depth per segment we calculated the average of all soundings printed on the chart for each segment. The volume of fresh water in each segment was calculated using surface and bottom salinity values in each segment compared to a saline end member value. Total volume of freshwater was divided by river flow to obtain flushing time. The inverse of flushing time is flushing rate. Salinity distribution for each sample run was combined with associated, lagged monthly discharge from Kinston, NC (U.S. Geological Survey records for Gage Station No. 02089500) and volume of estuarine segment. Flushing rates for all sampling dates within a season were averaged and then inverted for average flushing time. As the time scales of flushing were on the order of months, averaging of discharge values over a month was considered appropriate. The most saline 'end member' for each run was considered as the bottom water salinity from Stn $A$, except when salinities throughout the estuary were low. Previously, we inferred from nutrient data that the salinity of Pamlico Sound water was no less than 14 ppt (Christian et al. 1989). Therefore, when bottom water from Stn A was less than $14 \mathrm{ppt}$, we used $14 \mathrm{ppt}$ for the flushing time calculation.

Data for each nutrient variable during each of 16 seasons were combined to obtain volume-weighted mean concentrations. The volumes of segments increased down-estuary, and each site was considered as representative of a unique amount of water within the system. Individual daily concentrations were multiplied by segment volume, resultant quantities were summed, and the sum was divided by total volume. Daily volume-weighted means were averaged over each season for the 4 yr study. Spearman rank correlation analyses were used to assess relationships between the various volume-weighted variables and between nutrients and environmental factors.

To further evaluate biological and physical controls on nutrient concentration patterns, we constructed property versus salinity plots for extremes of temperature and flushing rates. Volume-weighted temperature was used as a surrogate for relative biological activity. We plotted results from a matrix of 4 conditions, each including data from 3 consecutive sampling dates during the 4 yr study. Station designation was indicated in each figure to assess the relationship among salinity structure, nutrient status, and physical position within the estuary.

\section{RESULTS}

\section{Physical features}

In Fig. 2 we show monthly mean surface water temperatures for all stations in the estuary and monthly 


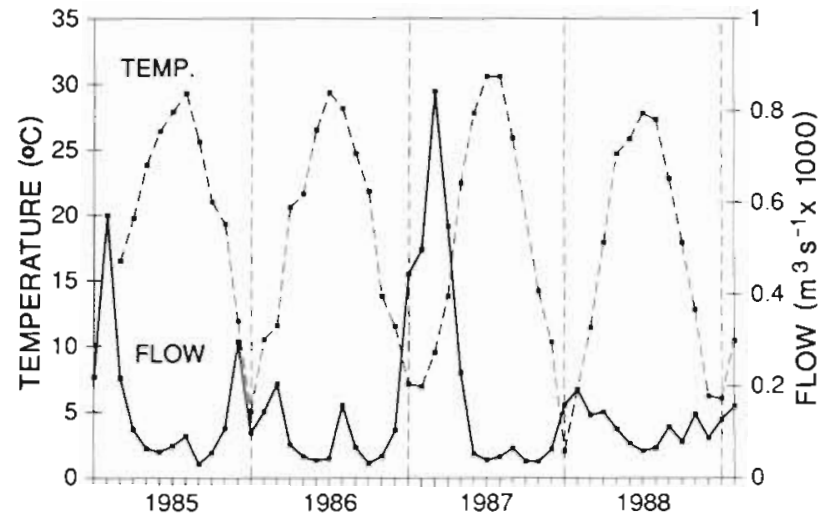

Fig. 2. Monthly mean surface water temperatures $\left({ }^{\circ} \mathrm{C}\right)$ within the Neuse River Estuary and discharges of water at the nearest upstream gaging station on the Neuse River (Kinston, NC) $\left(\mathrm{m}^{3} \mathrm{~s}^{-1}\right)$

mean discharges at the nearest upstream gaging station on the Neuse River (Kinston, NC). Surface water temperatures ranged from below $5^{\circ} \mathrm{C}$ in winter to above $30^{\circ} \mathrm{C}$ in summer. Seasonal patterns were similar from year to year, and seasonal differences between years were generally within a few degrees. Also, on any single date, little difference in temperature was found among stations or depths within a station.

Neuse River discharge varied considerably among seasons and years. The Trent River also empties into the estuary, but its watershed is only $9 \%$ of that of the Neuse and Trent combined, and patterns of discharge are similar between the 2 rivers. Monthly mean flows at Kinston varied almost 30 -fold during the 4 yr from $10 \mathrm{~m}^{3} \mathrm{~s}^{-1}$ in September 1985 to $295 \mathrm{~m}^{3} \mathrm{~s}^{-1}$ in March 1987. The latter value was 3.6 times the long-term average Kinston flow, and high flows during the early months of 1987 combined to produce a major flushing of the system. Relatively high flows occurred during winter and spring with lower flows in summer and fall. Again the highest winter-spring discharges were for 1986-87, high flows were noted before our sampling began in 1985, and relatively low flows were found in

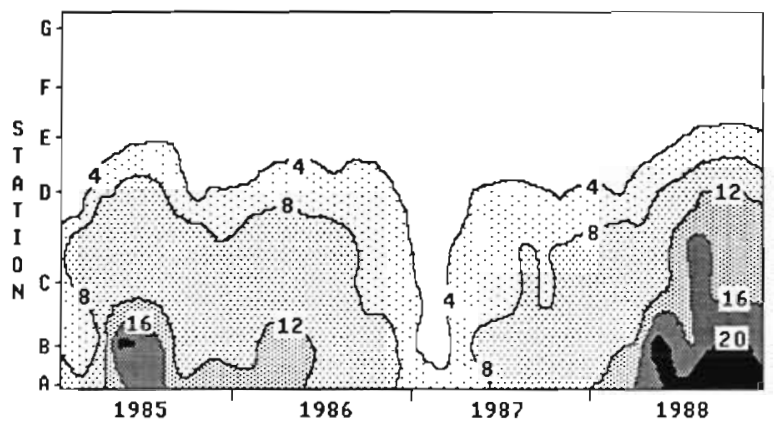

Fig. 3. Distribution of surface water salinity from March 1985 to February 1989
1985-86 and 1987-88 winter-spring periods. The lowest summer-fall flows were during a drought in 1987 , summer-fall flows in 1985 and 1986 were similar, and highest summer-fall flows were in 1988. Periods of low flow were often punctuated by high flows not adequately reflected in monthly or seasonal averages. Within August 1986, daily discharge rose to a high of $139 \mathrm{~m}^{3} \mathrm{~s}^{-1}$ after the previous 3 mo averaged $14.4 \mathrm{~m}^{3}$ $\mathrm{s}^{-1}$. Overall, the 4 yг of river flow data showed considerable variation in flow patterns that could affect the estuary.

The horizontal distribution of surface salinity was typical of a shallow, river-dominated estuary with the exception that the highest salinities rarely exceeded 20 ppt (Fig. 3). The adjacent Pamlico Sound maintains salinities in the range of 15 to 20 ppt (Giese et al. 1979); therefore, the downstream end-member salinity is less than seawater. Stn G, most upriver, rarely had measurable salinity. Over the $4 \mathrm{yr}$, surface salinity patterns reflected discharge patterns but with lags to flow pulses and dampened oscillations. In 1985, salinities were lowest after high winter flows. Salinities at estuarine stations then rose through summer and fall, fell in winter, and remained relatively constant or rose throughout 1986. The high flows in winter-spring 1986-87 brought salinities to their 4 yr low. From summer 1987, salinities increased over the long term, although responses to periodic high flows were seen. The upper estuary's salinities were more responsive to flow than were those in the lower estuary.

Bottom water salinities (not shown) followed the same general trends as surface salinities. As expected, however, bottom salinities were often higher than those at the surface. Vertical stratification of the water column was more dependent on salinity than on temperature, and frequency of stratification varied with station. Stratification was not a permanent feature at any station, but occurred most often in the upper estuary.

We computed estuarine flushing times from salinity distributions and freshwater discharges from the Neuse

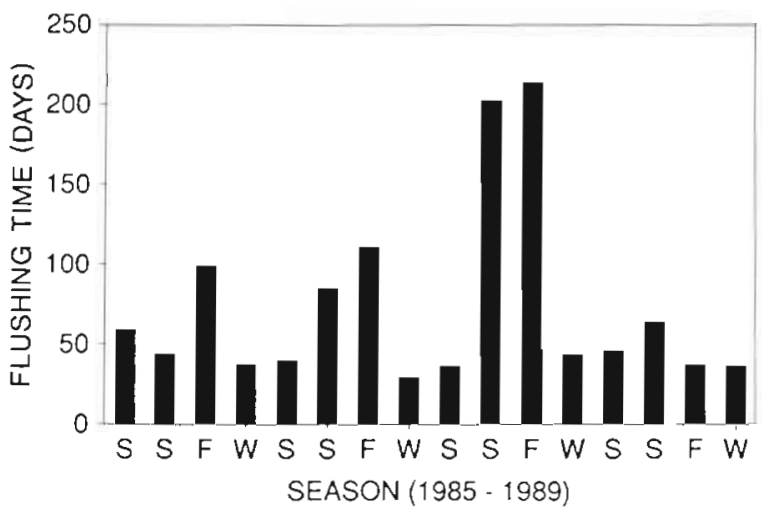

Fig. 4. Seasonally averaged flushing times 
River. Seasonal averages are shown in Fig. 4. The overall mean flushing time based on seasonal averaging over the $4 \mathrm{yr}$ was $51 \mathrm{~d}$, ranging from 30 to $215 \mathrm{~d}$. Given this time scale, our sampling frequency generally allowed for at least 2 samplings of each water mass as it passed through the estuary. Longest flushing times within a year occurred in fall of the first $3 \mathrm{yr}$ and in summer of 1987 and 1988. Winter flushing times were shortest among seasons in all years, and yearly flushing time was shortest in the last year.

\section{Spatial distribution}

The descriptive statistics by station for 7 nutrient variables and chl a are shown in Table 1 . We originally calculated 4 descriptors or moments of data distribu- tion: the arithmetic mean, standard deviation, skewness $\left(g_{1}\right)$ and kurtosis $\left(g_{2}\right)$. The latter 2 moments describe aspects of non-normal distributions with skewness reflecting extended tailing of high (positive $g_{1}$ ) or low (negative $g_{1}$ ) sample values beyond that predicted by normal distribution. Significant positive kurtosis (leptokurtosis) occurs when data are overly clustered around the mean and near the tails, whereas negative kurtosis (platykurtosis) reflects more data at intermediate values between mean and tails (Sokal \& Rohlf 1981). Dispersion of the data for any variable within a station was often considerable and non-normal. Thus, standard deviations often exceeded means and skewness and kurtosis were significant. Station means for a number of variables differed substantially along the transect, and standard deviations tended to be dependent on means. Therefore, we calculated

Table 1. Distribution of chlorophyll a and nutrient concentrations for $4 \mathrm{yr}$ in the Neuse River Estuary

\begin{tabular}{|c|c|c|c|c|c|c|c|c|}
\hline & & $G$ & $\mathrm{~F}$ & $E$ & $\begin{array}{c}\text { Station } \\
\text { D }\end{array}$ & $\mathrm{C}$ & $\mathrm{B}$ & A \\
\hline \multirow{4}{*}{$\begin{array}{l}\text { Chl a } \\
\left(\mu \mathrm{g} \mathrm{l}^{-1}\right)\end{array}$} & $\bar{x}$ & 6.0 & 8.0 & 24.9 & 25.9 & 14.7 & 11.8 & 10.5 \\
\hline & $\mathrm{SD}$ & 8.0 & 9.2 & 28.2 & 16.3 & 9.1 & 9.4 & 11.2 \\
\hline & $\mathrm{CV}$ & 133.3 & 115.0 & 113.3 & 62.9 & 61.9 & 79.7 & 106.7 \\
\hline & $g_{1} / g_{2}^{a}$ & $+1+$ & $+1+$ & $+1+$ & $\mathrm{ns} / \mathrm{ns}$ & $+/ \mathrm{ns}$ & $+1+$ & $+/+$ \\
\hline \multirow{4}{*}{$\begin{array}{l}\mathrm{NO}_{x} \\
(\mu \mathrm{M})\end{array}$} & $\overline{\mathrm{x}}$ & 65.0 & 54.4 & 32.9 & 9.4 & 3.2 & 2.1 & 1.2 \\
\hline & SD & 26.1 & 27.2 & 23.3 & 15.4 & 8.2 & 6.0 & 1.9 \\
\hline & $\mathrm{CV}$ & 40.2 & 50.0 & 70.8 & 163.8 & 256.3 & 285.7 & 158.3 \\
\hline & $g_{1} / g_{2}$ & $\mathrm{~ns} / \mathrm{ns}$ & $+/ \mathrm{ns}$ & $+/ \mathrm{ns}$ & $+1+$ & $+1+$ & $+1+$ & $+/+$ \\
\hline \multirow{4}{*}{$\begin{array}{l}\mathrm{NH}_{4} \\
(\mu \mathrm{M})\end{array}$} & $\overline{\mathrm{x}}$ & 7.0 & 10.2 & 8.3 & 2.7 & 2.0 & 2.3 & 3.1 \\
\hline & $\mathrm{SD}$ & 5.0 & 5.0 & 8.0 & 3.0 & 2.2 & 3.0 & 2.5 \\
\hline & $\mathrm{CV}$ & 71.4 & 49.0 & 96.4 & 111.1 & 110.0 & 130.4 & 80.6 \\
\hline & $g_{1} / g_{2}$ & $+1+$ & $\mathrm{ns} / \mathrm{ns}$ & $+1+$ & $+1+$ & $+/+$ & $+1+$ & $+/ \mathrm{ns}$ \\
\hline \multirow{4}{*}{$\begin{array}{l}\text { Urea }^{b} \\
(\mu M)\end{array}$} & $\bar{x}$ & 3.0 & 3.1 & 3.2 & 1.9 & 1.4 & 1.8 & 1.3 \\
\hline & $\mathrm{SD}$ & 2.2 & 4.9 & 4.1 & 2.1 & 1.9 & 2.6 & 1.4 \\
\hline & $\mathrm{CV}$ & 73.3 & 158.1 & 128.1 & 110.5 & 135.7 & 144.4 & 107.7 \\
\hline & $g_{1} / g_{2}$ & $\mathrm{~ns} / \mathrm{ns}$ & $+1+$ & $+1+$ & $+1+$ & $+1+$ & $+1+$ & $+1+$ \\
\hline \multirow{4}{*}{$\begin{array}{l}\text { DKN } \\
(\mu \mathrm{M})\end{array}$} & $\overline{\mathrm{x}}$ & 30.1 & 37.4 & 35.6 & 26.6 & 24.5 & 21.8 & 22.4 \\
\hline & $\mathrm{SD}$ & 15.0 & 16.7 & 18.6 & 12.9 & 13.2 & 9.9 & 12.0 \\
\hline & $\mathrm{CV}$ & 49.8 & 44.7 & 52.2 & 48.5 & 53.9 & 45.4 & 53.6 \\
\hline & $g_{1} / g_{2}$ & $\mathrm{~ns} /+$ & $\mathrm{ns} / \mathrm{ns}$ & $+1+$ & $\mathrm{ns} / \mathrm{ns}$ & $+1+$ & $\mathrm{ns} / \mathrm{ns}$ & $\mathrm{ns} / \mathrm{ns}$ \\
\hline \multirow{4}{*}{$\begin{array}{l}\text { PN } \\
(\mu \mathrm{M})\end{array}$} & $\overline{\mathrm{x}}$ & 5.8 & 7.3 & 16.9 & 19.9 & 16.3 & 14.8 & 13.2 \\
\hline & $\mathrm{SD}$ & 6.3 & 5.6 & 14.7 & 8.6 & 6.4 & 8.2 & 7.7 \\
\hline & $\mathrm{CV}$ & 108.6 & 76.7 & 87.0 & 43.2 & 39.3 & 55.4 & 58.3 \\
\hline & $g_{1} / g_{2}$ & $+/+$ & $+1+$ & $+1+$ & $\mathrm{ns} / \mathrm{ns}$ & $\mathrm{ns} / \mathrm{ns}$ & $+1+$ & $+1+$ \\
\hline \multirow{4}{*}{$\begin{array}{l}\text { FRP } \\
(\mu \mathrm{M})\end{array}$} & $\bar{x}$ & 6.4 & 5.4 & 4.6 & 3.1 & 2.3 & 1.8 & 1.7 \\
\hline & SD & 3.2 & 2.4 & 2.7 & 6.3 & 2.1 & 1.6 & 1.6 \\
\hline & $\mathrm{CV}$ & 50.0 & 44.4 & 58.7 & 203.2 & 91.3 & 88.9 & 94.1 \\
\hline & $g_{1} / g_{2}$ & $+1+$ & $\mathrm{ns} / \mathrm{ns}$ & $+/ \mathrm{ns}$ & $+/ \mathrm{ns}$ & $+/ \mathrm{ns}$ & $+/ \mathrm{ns}$ & $+1+$ \\
\hline \multirow{4}{*}{$\begin{array}{l}\mathrm{PP} \\
(\mu \mathrm{M})\end{array}$} & $\bar{x}$ & 1.4 & 1.3 & 1.8 & 1.8 & 1.3 & 1.0 & 0.9 \\
\hline & $\mathrm{SD}$ & 0.9 & 0.8 & 1.0 & 0.9 & 0.6 & 0.6 & 0.4 \\
\hline & $\mathrm{CV}$ & 64.3 & 61.5 & 55.6 & 50.0 & 46.2 & 60.0 & 44.4 \\
\hline & $g_{1} / g_{2}$ & $+1+$ & $\mathrm{ns} / \mathrm{ns}$ & $+/ \mathrm{ns}$ & $\mathrm{ns} / \mathrm{ns}$ & $\mathrm{ns} / \mathrm{ns}$ & $\mathrm{ns} / \mathrm{ns}$ & $+1+$ \\
\hline
\end{tabular}


coefficients of variation (CV) to compare relative dispersion within stations. Only DKN and PP had coefficients of variation less than $100 \%$ for all stations, and PN and FRP had CVs over $100 \%$ for only one station. $C h l$ a had highest CVs at the upper stations, whereas CVs for $\mathrm{NO}_{x}$ were highest at down-estuary lower stations. The pattern for $\mathrm{CV}$ of $\mathrm{NH}_{4}$ was similar to that for $\mathrm{NO}_{x}$, and urea CVs exceeded $100 \%$ at all but Stn $\mathrm{G}$. Thus, no single pattern of degree of dispersion across the estuary was found for all variables, and the variation associated with each variable was considerable.

The variability associated with each grand mean from the 4 yr embodies the intrasample run variation for each station. The variation expected for the mean of a station at the time of sampling was evaluated on 11 May 1988 for $\mathrm{NO}_{x}, \mathrm{NH}_{4}$, urea, DKN, PN, FRP, and PP. As expected, the within-sample date variation was generally less than found for the $4 \mathrm{yr}$. The intra-sample run coefficients of variation were less than those for $4 \mathrm{yr}$ in 25 of 28 comparisons. In the 3 instances where intrasample run coefficients of variation exceeded the $4 \mathrm{yr}$ coefficients $\left(\mathrm{NH}_{4}\right.$ at $\mathrm{D}$, urea at $\mathrm{A}$, and PP at $\left.\mathrm{A}\right)$, the intra-sample run means were less than $1 \mu \mathrm{M}$ and less than the 4 yr means. Intra-sample run standard deviations were independent of the means with the exception of $\mathrm{PN}$ and $\mathrm{NO}_{x}$ (where concentrations ranged from 0.5 to $82.6 \mu \mathrm{M})$. Such independence leads to high coefficients of variation for smaller means

Different patterns of distribution were also found among variables (Table 1 ). No variable was normally distributed for all stations. Both skewness $\left(g_{1}\right)$ and kurtosis $\left(g_{2}\right)$ were significant at the 0.01 level for all variables at least for one station; and when significant, $g_{1}$ and $g_{2}$ were positive. Thus data were skewed toward very high measurements and were clustered near the mean and tails. As expected, non-normality was most common when CVs were highest. Thus, patterns of non-normality were similar to those of CV.

The arithmetic mean was used as the descriptor of central tendency for the comparison among stations. Although distributions that are skewed toward high values tend to inflate sample arithmetic means relative to the true mean, no single transformation for data from all variables and stations was found to be adequate. Furthermore, in estimating the actual mass of material associated within a system, the arithmetic mean rather than the geometric mean or median was our descriptor of choice. As with the other statistical descriptors discussed, we found no pattern in means that characterized all variables. The following comparisons of means among stations are based on general trends of means and observations of the complete data set. Chl a concentrations were lowest in the river, peaked within the upper estuary, and declined toward the mouth. Concentrations of PN and PP also peaked within the

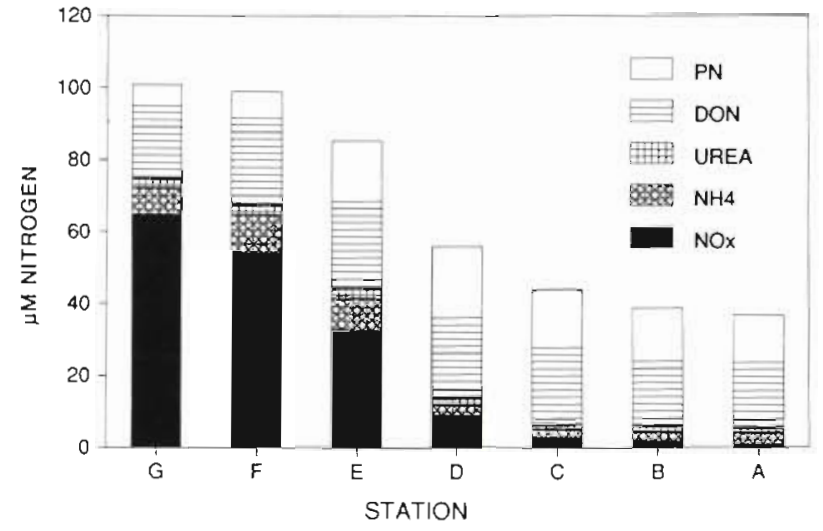

Fig. 5. Spatial distribution of 4 yr means of concentrations of $N$ species

upper estuary, reflecting their association with plankton. However, PP was high upriver, indicating its link to suspended sediment.

Patterns of nitrogen species are summarized in Fig. 5 as well as in Table 1. Clearly, $\mathrm{NO}_{x}$ dominates the total pool of $\mathrm{N}$ entering from fresh water, but was barely represented at the mouth of the estuary. The greatest decline in $\mathrm{NO}_{x}$ occurred on average within the upper estuary. Concentrations of $\mathrm{NH}_{4}$ rose as water passed the pulp and paper mill (between $G$ and F). Although the mean $\mathrm{NH}_{4}$ concentration at $\mathrm{E}$ was less than at $\mathrm{F}_{\text {, }}$ concentrations on 29 of 72 sampling dates were higher at $E$, perhaps reflecting effluent from the sewage treatment plant (between $F$ and $E$ ) in the lower river Concentrations fell within the upper estuary and rose in the lower estuary. Concentrations at A were higher than at $B$ for 48 of 68 sample dates. On 33 occasions both salinity and $\mathrm{NH}_{4}$ were higher at $A$ than $\mathrm{B}$; on 15 occasions $\mathrm{NH}_{4}$ was higher at A but salinity was not. Two years of urea data were collected (1987-88), and concentrations for this species at almost all stations were least among the $\mathrm{N}$ species considered. Urea concentrations fell from $3 \mu \mathrm{M}$ upriver to below $2 \mu \mathrm{M}$ in the lower estuary Dissolved organic nitrogen (DON) was calculated as the difference between DKN and $\mathrm{NH}_{4}$ For Fig. 5, urea is separated from DON; but because of limited data for urea, in further discussion we consider urea as part of DON. Concentrations of DON remained relatively constant throughout the estuary. The $\mathrm{N}$ pool was dominated by DON within the lower estuary as inorganic nutrient species declined. Concentrations of PN peaked in the upper estuary but remained a significant fraction of the pool in the lower estuary. The proportion of PN to the total $N$ increased down estuary.

Relationships between $\mathrm{N}$ and $\mathrm{P}$ distributions were also examined. FRP steadily declined down the estuary from $6.4 \mu \mathrm{M}$ at $\mathrm{G}$ to $1.7 \mu \mathrm{M}$ at $\mathrm{A}$ (Table 1). Ratios of $\mathrm{PN}$ to PP rose from 4 to 14 from the head to the mouth; in contrast, the ratios of dissolved inorganic nitrogen 
(DIN) to FRP were 11 or more upriver and declined to below 3 by Stn C (Fig. 6).

\section{Temporal distributions}

Volume-weighted nutrient and chl a concentrations were calculated to represent the best estimate of average concentration within the estuary for any given date. For most variables over 60 sample dates had sufficient data for the calculation. Exceptions were chlorophyll a $(n=55)$ and urea $(n=20)$. Such calculations do give relatively high weight to results from Stns $A$ and $B$, as the lower estuary accounts for almost twothirds of the estuary's volume. Thus, increases in volume-weighted concentrations could result from increased concentration within the whole estuary or the flushing of high concentrations from fresh water into the lower estuary. As a further data-reducing step and to filter out short-term variation, we calculated the arithmetic average of the volume-weighted concentrations for each of 16 seasons covered during the sampling (Table 2). Each season was represented by 2 to 6 sample dates.

Summer maxima in chl a were found in all 3 yr of measurement. Spring and fall concentrations were similar within a year and were comparable to or less than winter values. Furthermore, chl a concentration, volume-weighted and seasonally averaged, correlated positively with temperature $(p<0.05)$. The average for the 13 seasons was $14.3 \pm 4.6 \mu \mathrm{g} \mathrm{chl} \mathrm{a} 1^{-1}$ ( $\pm \mathrm{SD}$ ).

Patterns of volume-weighted concentrations of nitrogen varied among species (Table 2). Seasonal mean $\mathrm{NO}_{x}$ concentrations generally remained below $6 \mu \mathrm{M}$ with highest values each year in winter during highest flows and rapid flushing. The high flows during January and February 1987 resulted in rapid transport of $\mathrm{NO}_{x}$ down estuary and hence the unusually high concentration at this time. At this time seasonally averaged concentrations at $B$ and $C$ were nearly 10 times the 4 yr means, and at $A$ the concentration was over twice

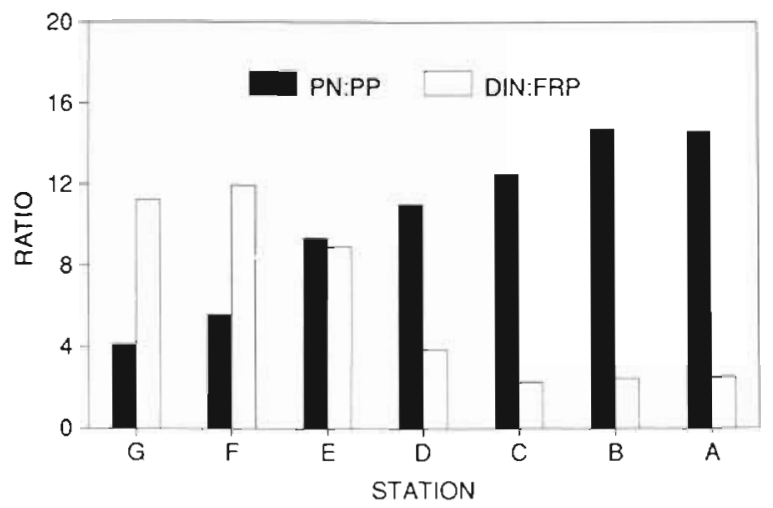

Fig. 6. Spatial distribution of 4 yr means of $N$ : P the long-term mean. During low flow periods and warmer temperatures, concentrations were low. Volume-weighted, seasonal concentrations of $\mathrm{NO}_{x}$ were positively correlated with flushing rate $(\mathrm{p}<0.05)$ but not with temperature $(p>0.05)$. Patterns in volumeweighted $\mathrm{NH}_{4}$ concentrations were less evident. During the first $3 \mathrm{yr}$, values ranged from less than $1 \mu \mathrm{M}$ to near $5 \mu \mathrm{M}$ with considerable change from one season to the next. During the last year when flushing was rapid but salinities high, concentrations were low and comparable among seasons. Concentrations of $\mathrm{NH}_{4}$ did not correlate with any tested variable. Fewer data were available for urea; however, concentrations for both 1987 and 1988 were highest in fall and lowest in winter. As with $\mathrm{NH}_{4}$, urea concentrations were lower in 1988 than previously. Volume-weighted DON concentrations (which include urea) were generally the highest among $\mathrm{N}$ species or were equally high to PN. The mean value in winter 1987-88 was exceptionally low, but represented 2 separate sample dates and analysis times. There was a significant Spearman rank correlation between flushing rate and volume-weighted DON $(\mathrm{p}<0.05$ ), but not between temperature and DON. Volume-weighted PN concentrations showed relatively little variation. Concentration in summer was highest or among the highest for a given year, and PN was positively correlated with temperature $(p<0.01)$, but not flushing rate. The high concentrations in summer appeared consistent at all stations throughout the transect (data not shown). Also, PN was highly correlated with chl a $(\mathrm{p}<0.01)$. Again unusually low concentrations were found in winter 1987-88. Overall, no strong seasonal patterns in all $\mathrm{N}$ species were observed that repeated for all $4 \mathrm{yr}$. Seasonal flushing rates correlated with $\mathrm{NO}_{x}$ and DON, but patterns were often hard to discern for other $\mathrm{N}$ species.

In contrast to the various dissolved $N$ species, FRP demonstrated a strong seasonal pattern of maxima in summers and minima in winters (Table 2). These seasonal trends were noted at all stations throughout the transect (data not shown). FRP correlated highly ( $p<$ $0.01)$ with both temperature and flushing rate. Volumeweighted PP concentrations were highest in summer of the last 3 yr, but seasons of minima varied. This pattern is similar to those of other particulate species; thus significant correlations were found for PP with chl a $(\mathrm{p}<0.01)$ and with PN $(\mathrm{p}<0.05)$.

\section{Property versus salinity distributions}

Nutrient patterns within the estuary were compared for (a) high temperature/slow flushing, (b) high temperature/rapid flushing, (c) low temperature/slow flushing, and (d) low temperature/rapid flushing condi- 
Table 2. Flushing rates and volume-weighted, seasonal averages of water temperature, salinity, and nutrient and chlorophyll a concentrations. Sp: spring; Su: summer; F: fall; W: winter

\begin{tabular}{|c|c|c|c|c|c|c|c|c|c|c|c|c|}
\hline Year & Season & $\begin{array}{l}\text { Flushing rate } \\
\qquad\left(d^{-1}\right)\end{array}$ & $\begin{array}{l}\text { Temp. } \\
\left({ }^{\circ} \mathrm{C}\right)\end{array}$ & $\begin{array}{l}\text { Salinity } \\
\text { (ppt) }\end{array}$ & $\begin{array}{c}\text { Chl a } \\
\left(\mathrm{kg} \mathrm{l}^{-1}\right)\end{array}$ & $\begin{array}{l}{\left[\mathrm{NO}_{x}\right]} \\
(\mu \mathrm{M})\end{array}$ & $\begin{array}{c}{\left[\mathrm{NH}_{4}\right]} \\
(\mu \mathrm{M})\end{array}$ & $\begin{array}{l}\text { [Urea] } \\
\text { (uM) }\end{array}$ & $\begin{array}{c}{[\mathrm{DON}]} \\
(\mu \mathrm{M})\end{array}$ & $\begin{array}{l}{[\mathrm{PN}]} \\
(\mu \mathrm{M})\end{array}$ & $\begin{array}{l}{[\mathrm{FRP}]} \\
(\mu \mathrm{M})\end{array}$ & $\begin{array}{l}{[\mathrm{PP}]} \\
(\mu \mathrm{M})\end{array}$ \\
\hline \multirow[t]{3}{*}{1985} & $\mathrm{Sp}$ & 0.017 & 20.9 & 6.0 & - & 1.6 & 4.5 & - & 23.9 & 12.9 & 1.1 & 1.3 \\
\hline & Su & 0.022 & 26.1 & 17.3 & - & 1.7 & 1.4 & - & 19.8 & 20.9 & 3.3 & 1.3 \\
\hline & $F$ & 0.010 & 19.8 & 12.5 & - & 1.3 & 2.6 & - & 10.4 & 17.0 & 1.4 & 1.2 \\
\hline \multirow[t]{4}{*}{1986} & W & 0.026 & 8.7 & 11.2 & 9.6 & 5.0 & 5.1 & - & 14.2 & 11.5 & 0.5 & 1.3 \\
\hline & $\mathrm{Sp}$ & 0.025 & 21.0 & 12.0 & 10.8 & 1.4 & 3.9 & - & 26.0 & 16.7 & 0.8 & 0.8 \\
\hline & Su & 0.012 & 27.7 & 11.1 & 19.9 & 4.2 & 2.2 & - & 28.9 & 17.0 & 4.9 & 1.5 \\
\hline & $F$ & 0.009 & 16.7 & 9.6 & 11.8 & 4.7 & 4.9 & - & 21.3 & 14.2 & 2.5 & 1.0 \\
\hline \multirow[t]{4}{*}{1987} & $W$ & 0.033 & 7.4 & 6.5 & 14.5 & 24.6 & 4.2 & - & 14.9 & 16.6 & 0.9 & 1.4 \\
\hline & $\mathrm{Sp}$ & 0.027 & 21.4 & 4.6 & 14.4 & 5.4 & 2.1 & - & 11.8 & 14.9 & 1.5 & 1.2 \\
\hline & Su & 0.005 & 28.4 & 8.4 & 23.3 & 2.0 & 3.2 & 2.2 & 27.6 & 16.9 & 4.5 & 1.6 \\
\hline & $F$ & 0.005 & 19.9 & 8.2 & 14.3 & 1.2 & 1.4 & 2.8 & 31.7 & 12.2 & 2.8 & 0.6 \\
\hline \multirow[t]{4}{*}{1988} & $W$ & 0.023 & 8.6 & 9.0 & 19.7 & 5.0 & 0.8 & 1.0 & 4.5 & 7.4 & 0.3 & 0.9 \\
\hline & $\mathrm{Sp}$ & 0.022 & 19.5 & 11.8 & 7.9 & 2.8 & 0.9 & 0.7 & 24.7 & 11.5 & 0.7 & 0.8 \\
\hline & Su & 0.016 & 22.3 & 17.2 & 17.0 & 2.0 & 1.5 & 1.5 & 23.0 & 20.6 & 2.6 & 1.5 \\
\hline & $F$ & 0.026 & 14.3 & 19.4 & 9.3 & 2.5 & 1.5 & 1.9 & 20.8 & 11.3 & 1.6 & 0.7 \\
\hline 1989 & W & 0.027 & 6.9 & 17.3 & 13.8 & 3.6 & 1.8 & 0.6 & 13.7 & 12.3 & 0.6 & 1.1 \\
\hline
\end{tabular}

tions. Each condition was represented by 3 consecutive sampling dates taken from the 4 yr of study (Table 3 ). Although in almost all instances the salinity at $\mathrm{A}$ was greater than $B$; at times, the salinity at $B$, or even $C$, exceeded $A$. Thus the inferred progression of nutrient concentration changes with salinity may not necessarily coincide with that associated with physical distance.

Under almost all conditions, $\mathrm{NO}_{x}$ declined to lowest concentrations upstream of the estuarine mouth, indicating nonconservative losses (Fig. 7). At high temperatures (high biological potential) and slow or fast flushing, concentrations declined to low levels by Stn D (Fig. 7a, b). At lower temperatures with slow flushing, $\mathrm{NO}_{x}$ still reached its lowest concentrations in the upper estuary (Fig. $7 \mathrm{C}$ ), but with low temperature and rapid flushing, $\mathrm{NO}_{x}$ concentrations remained high at Stns $\mathrm{C}$ and $B$ and the decrease in concentration was most nearly linear with salinity (Fig. $7 \mathrm{~d}$ ).

Patterns of $\mathrm{NH}_{4}$ concentration also reflected temperature and flushing rate and never displayed conservative mixing (Fig. 8). At high temperatures, concentrations were generally highest at $G, F$, and $E$, with concentrations at $F$ often exceeding those at $G$ (Fig. 8a, b). Concentrations below $E$ at high temperatures were variable with slow flushing (Fig. 8a) and were low with rapid flushing (Fig. 8b). At low temperatures and slow flushing, concentrations again were highest at $G, F$, and $E$, and then fell steadily to $C$ (Fig. $8 \mathrm{c}$ ). During the cold, rapidly flushing period, however, $\mathrm{NH}_{4}$ concentrations were low in the river, rose, and fell slightly toward the

Table 3. Dates and conditions for property versus salinity plots

\begin{tabular}{|c|c|c|c|}
\hline Grouping & Date & $\begin{array}{l}\text { Volume-weighted } \\
\text { temperature }\left({ }^{\circ} \mathrm{C}\right)\end{array}$ & $\begin{array}{l}\text { Flushing time } \\
\text { (d) }\end{array}$ \\
\hline (a) & $21 . J u l ~ 1987$ & 27.5 & 215 \\
\hline High temperature & 4 Aug 1987 & 30.4 & 234 \\
\hline Slow flushing & 1.8 Aug 1987 & 28.5 & 229 \\
\hline (b) & 24 May 1988 & 24.1 & 27 \\
\hline High temperature & 6 Jun 1988 & 22.0 & 41 \\
\hline Rapid flushing & 21 Jun 1988 & 19.5 & 51 \\
\hline (c) & 4 Dec 1986 & 12.9 & 245 \\
\hline Low temperature & 18 Dec 1986 & 10.6 & 150 \\
\hline Slow flushing & $7 \operatorname{Jan} 1987$ & 7.6 & 73 \\
\hline (d) & 3 Feb 1987 & 6.6 & 27 \\
\hline Low temperature & $25 \mathrm{Feb} 1987$ & 6.6 & - \\
\hline Rapid flushing & $18 \operatorname{Mar} 1987$ & 8.8 & 25 \\
\hline
\end{tabular}



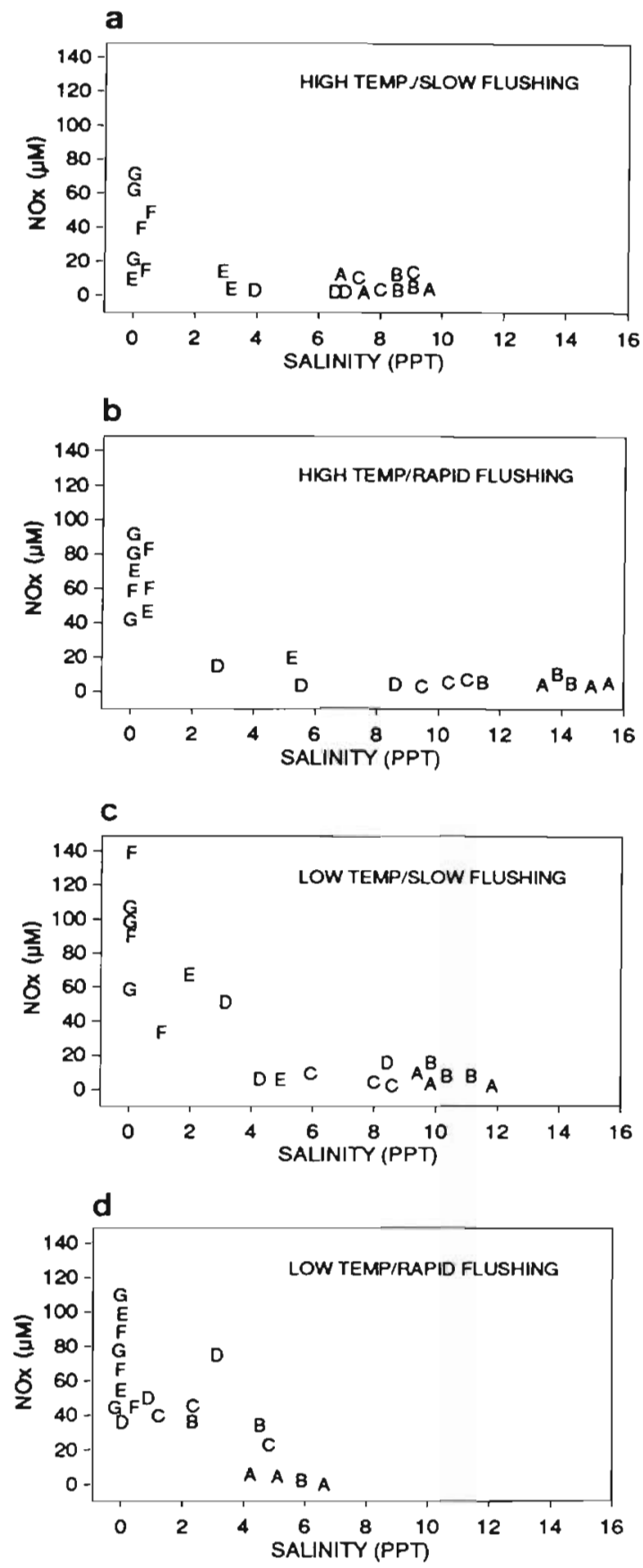

Fig. 7. $\mathrm{NO}_{x}$ versus salinity plots for 4 periods representing different conditions of temperatures and flushing times. Alphabetical designation of Figs. (a to d) as in Table 3

lower estuary (Fig. 8d). Under all conditions shown, $\mathrm{NH}_{4}$ concentrations at $\mathrm{A}$ were often greater than at $\mathrm{B}$.

Concentrations of PN showed repeatable trends along the estuary (Fig. 9). For almost all dates shown, the highest PN concentrations were found within the body of the estuary, not in the river or at the mouth. Thus, the estuary was a source for PN, although the
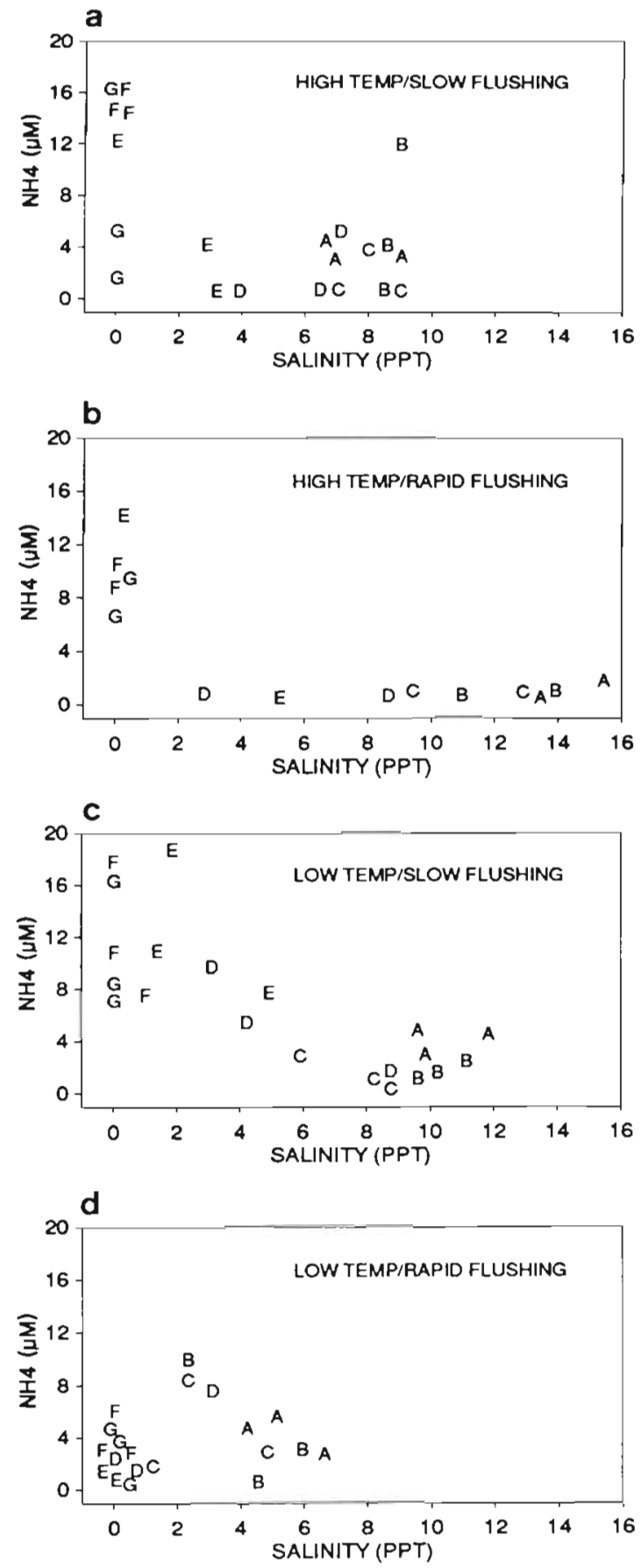

Fig. 8. $\mathrm{NH}_{4}$ versus salinity plots for 4 periods representing different conditions of temperatures and flushing times. Alphabetical designation of figures (a to d) as in Table 3

location of maximum concentration of PN shifted with temperature and flushing. With slow flushing independent of temperature, $P N$ tended to be maximum at $E$, D or C (Fig. 9a, c). With rapid flushing and high temperature, the maximum concentrations remained up-estuary (Fig. 9b). At low temperatures with rapid flushing, the maximum PN shifted down-estuary (Fig. 9d). 
Clear seasonal differences in FRP concentration patterns were found in the Neuse (Fig. 10). At high temperatures and slow flushing, concentrations were generally high but variable throughout the system (Fig. 10a). At all temperatures peak concentrations generally occurred either in the river or upper estuary, independent of flushing. Mixing did not appear conservative during warmer months, although the patterns were different between fast and slow flushing (Fig. 10a, b). At low temperatures, FRP concentrations tended toward a linear decrease down-estuary (Fig. 10c, d), but scatter was relatively high upstream.

Similar plots of DKN, DON and PP were also evaluated, but are not shown here. For DKN and DON variations between sampling dates and between stations during a sampling were so great as to mask any trend. Patterns for PP were like those for PN, although a riverine source of PP was noticeable during slow flushing and low temperatures.

\section{DISCUSSION}

\section{Modes of pattern description}

Description of nutrient distribution patterns is a common goal in many estuarine studies, but it is not necessarily achieved by common means. A wide variety of sampling options are available which may stress one or more aspects of the distribution patterns. At extremes, a single station can be repeatedly sampled to delineate temporal patterns (Litaker et al. 1987 ) or a horizontal transect along an estuary can be quickly and continuously or nearly-continuously monitored to approach synoptic sampling (Fisher et al. 1988). A synoptic sampling program can capture detailed spatial patterns (Fox et al. 1987), or sampling can focus on high frequency (hours) (Litaker et al. 1987 ) or low frequency (years) temporal variability (Nehring 1984). In considering the varieties of sampling programs, the spatial and temporal scales of concern and chemical species measured, it is understandable that a variety of descriptive procedures have been used. These include both graphic and equational procedures, such as property versus salinity plotting for spatial patterns (Boyle et al. 1974), time series analysis for temporal patterns (Hipel 1985), and contour plotting which graphically shows both patterns (Durand 1979). Our sampling program, consisting of 7 stations along an $80 \mathrm{~km}$ transect, from the head to the mouth of the Neuse River Estuary, was designed to observe changes on a spatial scale of tens of $\mathrm{km}$ and to observe changes on time scales of months, seasons, and years. We have analyzed data, in up to 3 different ways, to describe either spatial or temporal patterns or to evaluate potential causes for particular patterns.

In the following section, we combine the different analyses for each measured variable to provide an overall description of its dynamics within the Neuse River Estuary. However, we preface this discussion with comments on the general results of the 3 descriptive analyses themselves. Intrastation data were most
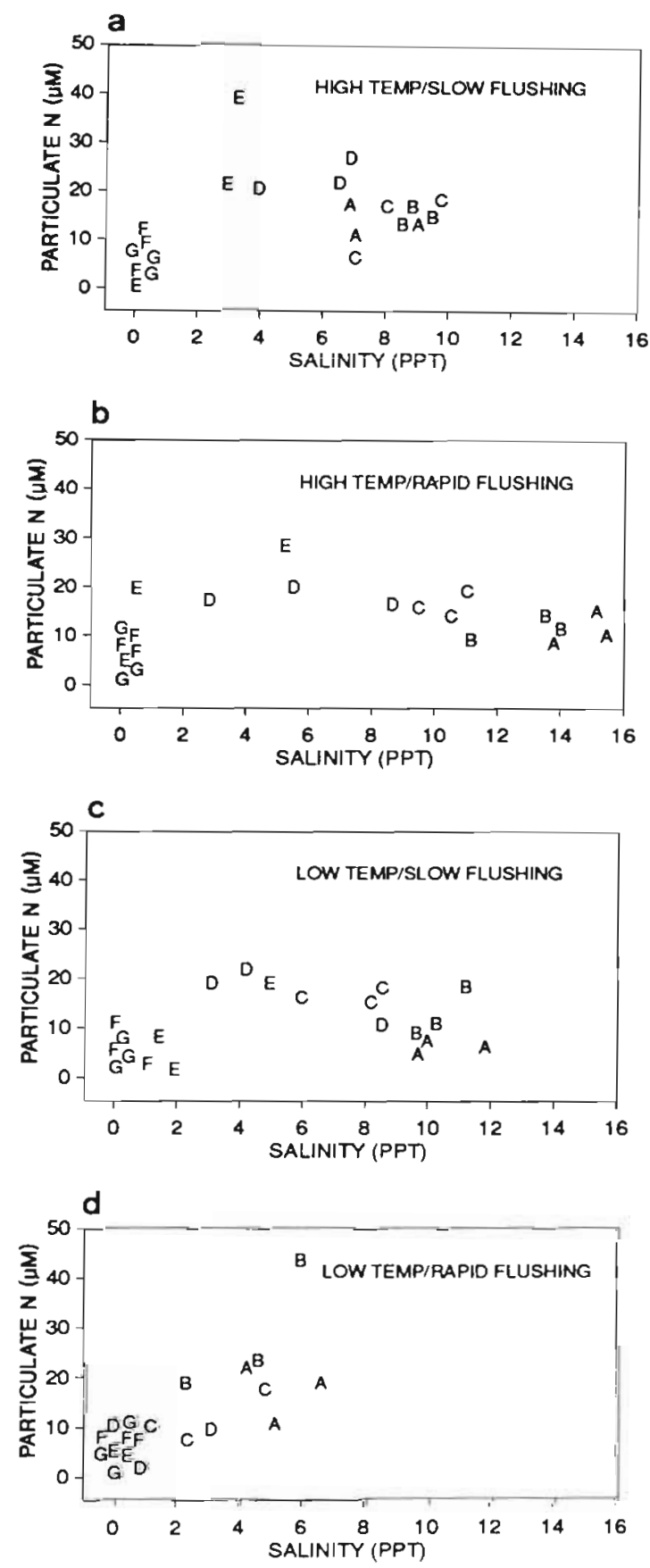

Fig. 9. PN versus salınity plots for 4 perods representing different conditions of temperatures and flushing times. Alphabetical designation of figures (a to d) as in Table 3 
commonly 'skewed to the right', resulting from a relatively large number of samples with high concentrations (Table 1). Frequently, data were also leptokurtoic, indicating a disproportionate number of samples near the 'tails' and mean (Sokal \& Rohlf 1981). Measured concentrations are the result of a variety of factors acting with different intensities on the chemical
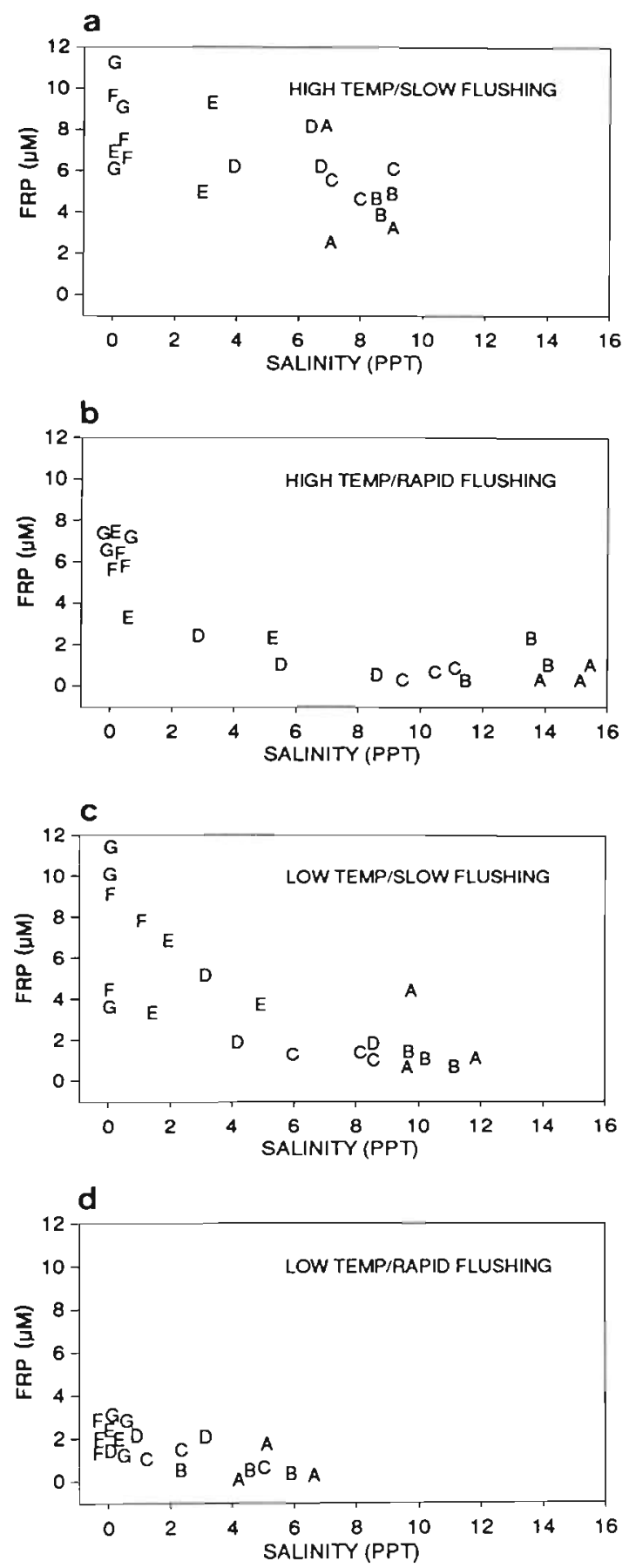

Fig. 10. FRP versus salinity plots for four periods representing different conditions of temperatures and flushing times. Alphabetical designations of figures (a to d) as in Table 3 species and fluctuating with different frequencies and phases of high and low activity (Imberger et al. 1983). For example, biological uptake of a nutrient may be regulated by light and temperature following diurnal and seasonal patterns. However, flushing and mixing may be more episodic with greatest impacts on concentration in winter when daily averaged temperature and light are least. Further, these physical factors may act directly on nutrients to transport larger or smaller quantities to or from a location or may act to transport organisms capable of the uptake or release. With such an array of factors affecting nutrient concentrations, non-normal distributions might be expected (West \& Shlesinger 1990). In fact, non-normality of water quality data may be more the rule than the exception (Christian \& Pipes 1983, Crabtree et al. 1987).

We stress that our comparisons of means among stations are not based on statistical tests of significant differences but rather on general trends and observations of the complete data sets for the various chemical species. The data sets involve large sample sizes (generally greater than 60 sample runs), non-independent samples, a variety of non-normal distributions, and 2way classification (time and location). Statistical tests for significant differences and ranking of variables for these conditions are problematic to say the least.

Assessing temporal changes and correlations between variables was accomplished only after both spatial and temporal averaging (Table 2). For any one sampling, concentrations could differ among stations by 10 -fold or more. Concentrations of some variables were often highest for the 2 river stations which represented less than $1 \%$ of the volume. Therefore, volume weighting was performed to evaluate systemwide average concentrations. Such volume weighting is important for interestuarine comparisons as well as intraestuarine studies, such as ours (Nixon 1983). There exist 3 potential limitations to the accuracy of our volume-weighted means. First, they are heavily weighted to values from $A$ and $B$ as these stations represent two-thirds of the estuary's volume. Original station choice was by distance rather than volume considerations. Second, during periods of stratification, concentrations in bottom waters may be significantly different from in surface waters, but only surface water values were used in calculations. However, stratification occurred frequently only in the upper estuary (unpubl. data), and the probable volume of affected bottom water was small relative to estuarine volume. Third, volume changes within the estuary due to winds, river discharge, and tides were ignored, and a standard volume was used. We assume that volume changes per section would be proportional to changes in total volume, and therefore have little impact on the overall mean. 
Seasonal averaging of volume-weighted means further removed extreme values for evaluation of temporal changes. We averaged by recognized seasons for several reasons. First, temperature patterns in the estuary were readily discriminated as high, low, and transitional levels based on equinox/solstice divisions. Second, a period of $3 \mathrm{mo}$ is long enough to encompass at least one flushing time under most cases (Fig. 4). Third, generally, over two-thirds of the seasons were represented by 4 or more sample runs. Lastly, inter-estuary comparisons may be made more easily using seasonal averages. The averages were analyzed by Spearman rank correlation for associations between variables, thus reducing the influence of unusually high or low values.

We employed modified property versus salinity plots to evaluate the relative importance of biological activity and flushing rate on nutrient concentrations (Figs. 7 to 10). Rates of biological processing of $N$ and primary productivity were measured as described elsewhere (Boyer et al. 1988, Boyer et al. unpubl., Stanley et al. unpubl.). All measured rates were greater in warmer months than during other seasons. Also, as shown here, chlorophyll a concentrations were highest in summer. Therefore, we inferred that sampling dates during the warm months reflected periods of highest biological activity.

Flushing times, as we have calculated, represent the period required to replace the volume of fresh water in the estuary by river flow (Pilson 1985). Holding total volume constant, these times are thus dependent upon the calculated freshwater volume from salinity distribution and upon discharge into the estuary. The results are somewhat counter-intuitive in that periods of high salinity in the estuary, which are normally associated with low flow conditions, are not necessarily associated with long flushing times. Also, low salinity is not necessarily associated with short flushing times. These conditions are reflected in the distributions of salinity with respect to station location shown in Figs. 7 to 10. In fact, flushing rate and volume-weighted salinity were not correlated. Two factors provide insight into this lack of correlation. First, the volume of fresh water decreases with higher salinities and thus a smaller volume of fresh water needs to be replaced as salinity increases. This takes less time for a given flow. Second, the salinity patterns within the Neuse River Estuary generally change very slowly in response to flow changes. After the severe decline in salinity during the spring of 1987, it took over 1 yr to return salinities to previous levels.

Property versus salinity plots are best interpreted when the estuary approaches steady state or where flushing time is short compared to the period of nutrient concentration change in the river (Sharp et al. 1986,
Cifuentes et al. 1990). We chose to combine sampling dates when flushing times and salinity patterns were similar among dates. Peterson et al. (1985) combined data from seasons representing different flow regimes, but, as described above, for the Neuse River Estuary, flushing time does not correlate well with discharge. We reasoned that flushing time is the variable which more directly affects nutrient concentration (Imberger et al. 1983). The success of our assumption of steady state can be evaluated by the stability of a station's salinity. Generally, stations in the river and at the lower estuary clustered around similar salinities, while salinities within the upper estuary fluctuated widely among the 3 dates per graph. Also, riverine concentrations of nutrients tended to be more variable among the 3 dates than those at the mouth. Such variability may promote nonlinearity in property vs salinity plots (Cifuentes et al. 1990). Fluctuations of concentrations among dates were generally greater during rapid flushing periods when sampling intervals were of the same order as flushing times. We infer that differences among dates may jeopardize interpretations based on single sampling dates in estuaries with long but variable flushing times such as the Neuse - a conclusion supporting the need for more developed models such as that presented by Cifuentes et al. (1990).

\section{Distribution of nitrogen}

Under virtually all conditions, riverine loading of nitrogen was dominated by DIN, and water leaving the mouth of the estuary was predominantly DON and PN. The major riverine component of DIN was nitrate as found for most estuaries receiving fresh water from largely non-urban areas (Durand 1979, Stanley \& Hobbie 1981, Filardo \& Dunstan 1985, Fisher et al. 1988). Although concentrations of both $\mathrm{NO}_{x}$ and $\mathrm{NH}_{4}$ were more at the head than at the mouth of the estuary, mean $\mathrm{NH}_{4}$ comprised $10 \%$ of the riverine $\mathrm{DIN}$, but by the estuary's mouth mean $\mathrm{NH}_{4}$ was over $70 \%$ of the DIN. The pattern of increased proportions of $\mathrm{NH}_{4}$ in the DIN pool down-estuary reflected both net decreases in DIN from loading and increased importance of $\mathrm{N}$ recycling. The decreases in $\mathrm{NO}_{x}$ were nonconservative under most conditions but approached conservative dilution in winter during rapid flushing. Under these conditions, volume-weighted concentrations were maximum, and biological activities and often times for processing were minimum. At other times, $\mathrm{NO}_{x}$ was rapidly depleted in the upper estuary where planktonic assimilation of nitrate (Stanley et al. unpubl.) and benthic uptake of nitrate (W. M. Rizzo \& Christian unpubl.) were most active. No direct measures of denitrification were made, but this process has been found 
to be a significant contributor to $\mathrm{NO}_{x}$ concentration decline in other estuaries (Koike \& Sørenson 1988). Overall, the pattern of $\mathrm{NO}_{x}$ within the estuary was a monotonic decline down-estuary. Decrease in concentration relative to distance was negatively affected by rapid flushing and decreased biological activity.

Local sources of $\mathrm{NH}_{4}$ played an important role in determining the pattern of distribution of this nutrient. Concentrations often rose as water passed both a paper pulp mill and sewage treatment plant in the lower river. The increase in $\mathrm{NH}_{4}$ concentration resulting from the paper pulp mill effluent is apparent in the $4 \mathrm{yr}$ means. The influence of sewage effluent is less obvious, but increases at E relative to F occurred $40 \%$ of the time. At times the input from these point sources can be significant. For example, $70 \%$ of $\mathrm{NH}_{4}$ loading in the river below the paper pulp mill was associated with the mill's effluent during a low flow period in 1983 when only $9 \%$ of the water discharge was linked to the effluent (Christian et al. 1988). During cooler seasons increased concentrations were found throughout the upper estuary. Also, under almost all conditions, concentrations rose from mid-estuary to the mouth. This increase could come from regeneration within the lower Neuse River Estuary, from local fresh water discharge, or from intrusion of Pamlico Sound water with relatively high concentrations of $\mathrm{NH}_{4}$. Both benthic release of $\mathrm{NH}_{4}$ (Rizzo et al. unpubl.) and planktonic ammonification (authors unpubl. data) were active in the lower estuary. Also, on $29 \%$ of the occasions when concentrations were higher at A than B, salinity was lower at the former station. Thus local fresh water discharge may have been important at times. In comparing $\mathrm{NH}_{4}$ concentrations at Stn A over a range of salinities, Christian et al. (1989) found low concentrations associated with highest salinities, presumably of Sound waters. Thus intrusion from Pamlico Sound is the least plausible source. Within the estuary, ammonia uptake and turnover rates were rapid (Boyer et al. 1988). Point sources and rapid turnover relative to the long flushing times of the estuary are conducive to patchy distributions and high variability of this species (Imberger et al. 1983). Such patchiness and variability for $\mathrm{NH}_{4}$ have been noted in other estuaries (Fisher et al. 1988, Meybeck et al. 1988, McPherson \& Miller 1990).

Dissolved organic nitrogen was calculated as DKN minus $\mathrm{NH}_{4}$ and averaged ca $10 \%$ urea. DON, DKN, and urea concentrations were highest from Stns $G$ to $E$ and declined slowly within the estuary. Coefficients of variation were relatively low for DKN but not urea. These patterns and the correlation of DON with flushing rate but not temperature probably reflect a long biological turnover time for the DON as the major component of DKN. The turnover rate of urea was relatively rapid (Stanley et al. unpubl.) as with other estuarine systems (Kaufman et al. 1983, Furnas et al. 1986), but the roles of other components of DON in nitrogen cycling are largely unknown (Sharp 1983). In fact, our measurement of DON may be inadequate (Suzuki \& Sugimura 1985). Until better methods can be employed, the significance of DON to estuarine nitrogen cycling remains to be determined for this and other estuaries.

Particulate nitrogen closely corresponded to chlorophyll a concentrations. Both rose with warmer temperatures and were highest in the upper estuary where volumetric photosynthesis and ammonia uptake rates were maximum (Boyer et al. 1988, Boyer et al. unpubl.). The upper estuary was often the region of a relatively ill-defined turbidity maximum. The increase in PN in this region relative to upstream was most probably the result of autochthonous organic matter production. Rapid flushing extended the region into the lower estuary. Comparable controls of seston by the interaction of flow regimes with biological activity have been recognized for a number of other estuaries (Sharp et al. 1982, Filardo \& Dunstan 1985, Relexans et al. 1988) and conforms to the conceptual model of Fisher et al. (1988).

\section{Distribution of phosphorus}

Filterable reactive phosphorus concentrations displayed strong seasonality with maxima in summer, especially when flushing time was long. However, the general spatial pattern was one of decrease in concentration from head to mouth of the estuary. Thus, no one region in the estuary appeared to commonly act as a net source for FRP; rather system-wide regeneration was enhanced during warmer months. As flushing rate slowed, the time for accumulation of FRP increased and overall concentrations rose. We infer that increased FRP and decreased DIN concentrations in summer during high photosynthetic demands for nutrients are indicative that phosphorus does not limit primary productivity. The increase in FRP in summer has been seen elsewhere (Taft \& Taylor 1976), but it is not a universal result for river-dominated estuaries.

Particulate phosphorus correlated positively with other seston variables, being maximum in warmer months and generally in the upper estuary. However, upriver concentrations were relatively high, and PN : PP ratios for riverine samples were below 6 . We interpret these upstream concentrations of $\mathrm{PP}$ to be associated with suspended sediments. Further down the estuary seston became dominated by planktonderived material causing PN : PP to rise to near Redfield ratio values (Redfield 1958). The greatest increase in 
ratio was in the upper estuary, the site of the weak turbidity maximum and high biological activity conforming to the model of Fisher et al. (1988).

\section{Overview}

Many of the characteristics of nutrient concentration patterns for the Neuse River Estuary are similar to those of other river-dominated estuaries. However, an interesting aspect of this system is its long flushing times. For example, flushing times for the Neuse River Estuary generally exceed those for the Loire Estuary (Relexans et al. 1988), Tamar Estuary (SW England) (Uncles et al. 1983), Narragansett Bay (Pilson 1985), and even Chesapeake Bay (Baird \& Ulanowicz 1989). Flushing times for the Neuse are slightly more than for San Francisco Bay but less than for the Delaware Bay (Cifuentes et al. 1990). The long flushing times are a result of its large volume relative to freshwater input and its output to Pamlico Sound instead of the ocean. The average flushing time of Pamlico Sound is $11 \mathrm{mo}$ (Giese et al. 1979). The average flushing time of the Neuse River Estuary is almost 2 mo, and it can take several flushing times to reestablish 'normal' salinity patterns after strong freshets. Further, tidal energy is minimized by the presence of narrow inlets and small tidal exchange relative to volume in Pamlico Sound which reduces vertical mixing and blocks upstream water intrusions. Given these conditions, nutrient species' distributions strongly respond to biological activity. Biological turnover times are of the order of hours to days for most variables studied (Boyer et al. 1988, Stanley et al. unpubl.). Conservative mixing was rarely found for the measured chemical species, signals from point sources were evident, autochthonous production was noted as upper estuary maxima of particulates, and variability was considerable. These all characterize conditions in which time scales of biological or chemical turnover and/or of interface exchange are rapid relative to mixing time scales (Imberger et al. 1983).

The Neuse River Estuary is one of 3 major tributary estuaries of the Albemarle-Pamlico Sound complex of North Carolina. The nutrient distributions and cycling patterns of all three (Neuse, Pamlico, and Chowan) have been studied at various times during the past 2 decades. Hobbie \& Smith (1975) reported nutrient concentrations along the Neuse River Estuary for the period 1970 to 1973. Nutrient concentration patterns were similar to those we report, and nutrient concentrations have not increased in a perceptible way over the intervening years. Stanley (1990) conducted a comprehersive analysis of nutrient concentration changes using 20 yr of data from the neighboring Pamlico River
Estuary and failed to find statistically significant increases for most measured variables. In the Chowan River, also, patterns during the mid-1970s were similar to ours (Stanley \& Hobbie 1981). In both the Chowan and Pamlico River Estuaries, nutrient cycling was rapid compared to the flushing times of fresh water (Kuenzler et al. 1979, Stanley \& Hobbie 1981), and nitrogen for phytoplankton production largely came from internal recycling rather than loading from the tributary rivers. The importance of recycling is comparable in the Neuse River Estuary (Boyer et al. 1988, Stanley et al. unpubl.). Thus our findings for the Neuse River Estuary are similar to those for the neighboring estuaries.

The conceptual model developed by Fisher et al. (1988) from data from the Chesapeake, Delaware, and Hudson Bays is largely confirmed for the Neuse River Estuary. Primary productivity was generally low and nutrients high in the river, although maximum light limitation was not necessarily evident there (authors' unpubl. data). However, this pattern of low primary productivity and high nutrient concentrations in the River can be altered in summer as a result of occasional cyanobacterial blooms (Pearl 1987, Christian et al. 1988). At the estuarine head, primary productivity increased as dissolved inorganic nutrients declined and seston increased. Others (Morris et al. 1978, Filardo \& Dunstan 1985) have ascribed the enhanced production at the freshwater-seawater interface to the prior death and mineralization of freshwater algae. We have found little evidence for this mechanism (Christian et al. 1984) and consider it more likely that improved light conditions and extended residence time within the widened estuary promoted production (Boyer et al. unpubl.) Further down the estuary, nitrogen may have become limiting at times as concentrations of $\mathrm{NO}_{x}$ and $\mathrm{NH}_{4}$ periodically reached the limits of detection; while FRP, especially in warm seasons, remained high. In the lower estuary, DIN : FRP averaged below 3 and fell at times to below 1 . Concentrations of chlorophyll $a_{1}$ PN, and $\mathrm{PP}$ also fell, but their ratios were compatible with a largely organic, presumably planktonic, seston. Decreased particulate concentrations and Gelbstoff in the lower estuary promoted greater light penetration such that areal primary productivity and nutrient uptake were often higher than that up-estuary (Boyer et al. 1988). Periods of high flow pushed materials further into the estuary before biological processing could occur. However, even at high flows the residence time of materials was long enough in the estuary to accommodate significant cycling.

Acknowledgements. Support for this work was provided by the National Oceanic and Atmospheric Administration Office of Sea Grant under Grant NA85AA-D-SG022, and the State of North Carolina. The grant was administered by the University of North Carolina Sea Grant College Program. Also, support 
was provided by the U.S. Environmental Protection Agency under grant agreement R-812475-01-0. Further support was from Texasgulf Chemicals, Inc. We thank the following individuals for their assistance in field, laboratory, and clerical activities: A. Anderson, D. Daniel, K. Evans, L. Harper, M. Jones, G. Lackey, W. Rizzo, and R. Willis. We also thank M. M. Brinson and W. M. Rizzo for their comments on the manuscript.

\section{LITERATURE CITED}

American Public Health Association (APHA) (1985). Standard methods for the examination of water and wastewater, 16 th Edition. American Public Health Association, New York

Baird, D., Ulanowicz, R. E. (1989). The seasonal dynamics of the Chesapeake Bay ecosystem. Ecol. Monogr. 59: 329-364

Boyle, E., Collier, R., Dengler, A. T., Edmon, T. M., Ng, A. C., Stallord, R. F. (1974). On the chemical mass balance in estuaries. Geochim. Cosmochim. Acta 38: 1719-1728

Boyer, J. N., Stanley, D. W., Christian, R. R., Rizzo, W. M. (1988). Modulation of nitrogen loading impacts within an estuary. In: Lyke, W L., Hoban, T. J. (eds.) Proceedings N. C. Amer. Water Resources Assoc., Symposium on Coastal Water Resources. AWRA. Technical Publ. Series TPS-88-1. AWRA, Bethesda, MD, p. 165-176

Christian, R. R., Bryant, W. L. Jr, Stanley, D. W (1986). The relationship between river flow and Microcystis aeruginosa blooms in the Neuse River, North Carolina. Water Resources Research Institute of the University of North Carolina. Raleigh, NC. Report No. 223. 100 p

Christian, R. R., Pipes, W. O. (1983). Frequency distribution of coliforms in water distribution systems. Appl. environ. Microbiol. 45: 603-609

Christian, R. R., Rizzo, W. M., Stanley, D. W. (1989). Influence of nutrient loading on the Neuse River estuary, North Carolina. NOAA, National Undersea Research Prog., Res. Rep. 89-2, p. 19-40

Christian, R. R., Stanley, D. W., Daniel, D. A. (1984). Microbiological changes occurring at the freshwater-seawater interface of the Neuse River Estuary, North Carolina. In: Kennedy, V.S. (ed.) The estuary as a filter Academic Press, New York, p. 349-366

Christian, R. R., Stanley, D. W., Daniel, D. A. (1988). Characteristics of a blue-green algal bloom in the Neuse River, North Carolina. Univ. North Carolina Sea Grant College Program. Working Paper 87-2, Raleigh, NC. $71 \mathrm{p}$

Cifuentes, L. A., Schemel, L. E., Sharp, J. H. (1990). Qualitative and numerical analyses of the effects of river inflow variations on mixing diagrams in estuaries. Estuar. coast. Shelf Sci. 30: 411-427

Crabtree, R. W., Cluckle, I. D., Forster, C. F. (1987). Percentile estimation for water quality data. Wat. Res. 21: 583-590

Durand, J. B. (1979). Nutrient and hydrological effects of the pine barrens on neighboring estuaries. In: Forman, R. T T. (ed.) Pine barrens, ecosystem and landscape. Academic Press, New York, p. 195-211

Filardo, M. J., Dunstan, W. M. (1985). Hydrodynamic control of phytoplankton in low salinity waters of the James River Estuary, Virginia, USA. Estuar, coast. Shelf Sci. 21: $653-667$

Fisher, T R., Harding, L. W. Jr., Stanley, D. W., Ward, L. G. (1988). Phytoplankton, nutrients, and turbidity in the Chesapeake, Delaware and Hudson Estuaries. Estuar coast. Shelf Sci. 27: 61-93
Fox, L. E., Lipschultz, F., Kerkhof, L., Wofsy, S. C. (1987). A chemical survey of the Mississippi Estuary. Estuaries 10: $1-12$

Furnas, M. J., Smayda, T J., Deason, E. A. (1986). Nitrogen dynamics in lower Narragansett Bay. II. Phytoplankton uptake, depletion rates of nitrogenous nutrient pools, and estimates of ecosystem remineralization. J. Plankton Res. 8: 755-769

Giese, G. L., Wilder, H. B., Parker, G. G. (1979). Hydrology of major estuaries and sounds of North Carolina. U. S. Geological Survey, Water Resources Investigations, Raleigh, NC. Report No. 79-46. $175 \mathrm{p}$

Hipel, K. W. (1985). Time series analysis in perspective. Water Res. Bull. 21-609-624

Hobbie, J. E., Smith, N. W. (1975). Nutrients in the Neuse River Estuary. University of North Carolina Sea Grant Program. Report UNC-SG-75-21. Raleigh, NC. 183 p

Horrigan, S. G., Montoya, J. P., Nevias, J. L., McCarthy, J. J., Ducklow, H., Goericke, R., Malone, T. (1990). Nitrogenous nutrient transformations in the spring and fall in the Chesapeake Bay. Estuar. coast. Shelf Sci. 30: 369-391

Imberger, J., Berman, T., Christian, R. R., Sherr, E. B., Whitney, D. E., Pomeroy, L. R., Wiegert, R. G., Wiebe, W. J. (1983). The influence of water motion on the distribution and transport of materials in a salt marsh estuary. Limnol Oceanogr. 28: 201-214

Jones, M. N., Bradshaw, H. D. (1989). Copper: an alternative to mercury; more effective than zirconium in Kjeldahl digestion of ecological materials. Commun. Soil Sci. Plant Anal. 20: 1513-1524

Kaufman, Z. G., Lively, J. S., Carpenter, E. J. (1983). Uptake of nitrogenous nutrients by phytoplankton in a barrier island estuary: Great South Bay, New York. Estuar coast. Shelf Sci. 17: $483-493$

Ketchum, B. H. (1951). The exchanges of fresh and salt waters in tidal estuaries. J. mar Res. 10: 18-38

Koike, I., Sørensen, J. (1988). Nitrate reduction and denitrification in marine sediments. In: Blackburn, T. H., Sørensen, J. (eds.) Nitrogen cycling in coastal marine environments. SCOPE 33. John Wiley and Sons, New York, p. 251-273

Kuenzler, E. J., Stanley, D. W., Koenings, J. P. (1979). Nutrient kinetics of phytoplankton in the Pamlico River, North Carolina. Water Resources Research Institute of the University of North Carolina, Report No. 139. Raleigh. 163 p

Litaker, W., Duke, C. S., Kenney, B. E., Ramus, J. (1987). Shortterm environmental variability and phytoplankton abundance in a shallow tidal estuary. Mar. Biol. 96: 115-121

McCarthy, J. J. (1970). A urease method for urea in seawater. Limnol. Oceanogr 15: 309-313

McPherson, B. F., Miller, R. L. (1990). Nutrient distribution and variability in the Charlotte Harbor estuarine system, Florida. Water Res. Bull. 26: 67-80

Meybeck, M., Canwet, G., Dessery, S., Somville, M., Gouleau, D., Billen, G. (1988). Nutrients (organic C, P, N, Si) in the eutrophic River Loire (France) and its estuary. Estuar. coast. Shelf Sci. 27: 595-624

Morris, A. W., Mantoura, R. F. C., Bale, A. J., Howland, R. J. M. (1978), Very low salinity regions of estuaries: important sites for chemical and biological reactions. Nature, Lond. 274: 678-680

Nehring, D. (1984). Variations in the nutrient situation of the Baltic proper. Limnologica (Berl.) 15: 277-287

Nixon, S. W. (1983). Estuarine ecology: a comparative and experimental analysis using 14 estuaries and the MERL microcosm. Final report to the U.S. Environmental Protection Agency, Chesapeake Bay Program, Graduate School of Oceanography, University of Rhode Island, Kingston 
Officer, C. B. (1979). Discussion of the behavior of non-conservative dissolved constituents in estuaries. Estuar. coast. mar. Sci. 9: 91-94

Paerl, H. W. (1987). Dynamics of blue-green algal (Microcystis aeruginosa) blooms in the lower Neuse River, North Carolina: causative factors and potential controls. Water Resources Research Institute of the University of North Carolina. Raleigh, NC. Report No. 229. 164 p

Peterson, D. H., Smith, R. E., Hager, S. W., Harmon, D. D., Herndon, R. E., Schemel, L. E. (1985). Interannual variability in dissolved inorganic nutrients in Northern San Francisco Bay Estuary. Hydrobiologia 129: 37-58

Pilson, M. E. Q. (1985). On the residence time of water in Narragansett Bay. Estuaries 8: 2-14

Redfield, A. C. (1958). The biological control of chemical factors in the environment. Am. Sci. 46: 205-221

Relexans, J. C., Meybeck, M., Billen, G., Brugeaille, M. Etcheber, H., Somville, M. (1988). Algal and microbial processes involved in particulate organic matter dynamics in the Loire Estuary. Estuar. coast. Shelf Sci. 27: 625-644

Sharp, J. H. (1983). The distributions of inorganic nitrogen and dissolved and particulate organic nitrogen in the sea. In Carpenter, E. J., Capone, D. G. (eds.) Nitrogen in the marine environment. Academic Press, New York, p. 1-35

Sharp, J. H., Culberson, C. H., Church, T. M. (1982). The chemistry of the Delaware Estuary. General considerations. Limnol. Oceanogr. 27: 1015-1028

Sharp, J. H., Cifuentes, L. A., Coffin, R. B., Pennock, J. R., Wong, K. C. (1986). The influence of river variability on the circulation, chemistry, and microbiology of the Delaware Estuary. Estuaries 9: 261-269

This article was presented by G. W. Thayer, Beaufort, N. Carolina, USA
Sokal, R. R., Rohlf, F. J. (1981). Biometry, 2nd edn. W H. Freeman and Co., New York

Stanley, D. W. (1988). Historical trends in nutrient loading to the Neuse River Estuary, N. C. In: Lyke, W. L., Hoban, T. J. (eds.) Proc. Am. Water Resources Assoc., Symposium on Coastal Water Resources. AWRA Technical Publ. Series TPS-88-1. AWRA, Bethesda, MD, p. 155-164

Stanley, D. W. (1990). Historical trends in land use, nutrient production, water quality, and fisheries in the AlbemarlePamlico River estuarine system. Report to NOAA National Marine Pollution Program Office, Rockville, MD. 312 p

Stanley, D. W., Hobbie, J. E. (1981). Nitrogen recycling in a North Carolina coastal river. Limnol. Oceanogr 26 : $30-42$

Suzuki, Y., Sugimura, Y (1985). A catalytic oxidation method for the determination of total nitrogen dissolved in seawater. Mar. Chem. 16: 83-97

Taft, J. L., Taylor, W. R. (1976). Phosphorus dynamics in some coastal plain estuaries. In: Wiley, M. L. (ed.) Estuarine processes, Vol. I. Academic Press, New York, p. 79-89

Uncles, R. J., Bales, A. J., Howland, R. J. M., Morris, A. W., Elliot, R. C. A. (1983). Salinity of surface water in a partially-mixed estuary, and its dispersion at low run-off. Oceanologica Acta 6: 289-296

U. S. Environmental Protection Agency (USEPA) (1979). Methods for chemical analysis of water and wastes. U. S. Environmental Protection Agency. Washington, D. C.

West, B. J., Shlesinger, M. (1990). The noise in natural phenomena. Am. Sci. 78: 40-45

Wilkinson, L. (1988). SYSTAT: the system for statistics. SYSTAT, Inc., Evanston, Illinois

Manuscript first received: October 10, 1990

Revised version accepted: February 1, 1991 